men and women there is a striking and peculiar physiognomy, which is the same in hundreds of the sculptures; there are other traits equally persistent, and the ornamentation-of which there is so much on the figures, tablets, and vases, is unique, and pieserves a constant relation. The uniform observance of such characteristics in so large a number of objects, would seem to determine them as "typical," no matter who were the makers of them, or when they were made.

Dr. Rau believes, he says, that the "carvings" originated in comparatively modern times. I should be pleased to have any evidence either from colonial or other history of West North Carolina, that might throw light upon their production, as I have spent much valuable time in endeavouring to find such evidence.

Dr. Rau continues:- "They ("the carvings') were made by a few individuals of the Indian, or, perhaps, even of the Caucasian race." But he has already said that they do not "resemble the well-known specimens of modern Indian art." How, then, does he know that "they were made by a few individuals of the Indian race?" And I would ask why members either of the Indian or Caucasian races have chosen to make representations of other peoples than themselves, and with other characteristics than their own? Why Indians, who are notori. ously prone to war, should have, in their representations, so carefully absented all of its indications, and emphasised the pleasures and avocations of peace? And again, why-if the "carvings" were made by a Caucasian, the maker has so studiou.ly refrained from placing any letter, sign, or symbol, significant of his race or religion, on any of the 2000 objects?

"The rude attempts at imitating animals of the Old World," proceeds Dr. Rau, "are conclusive evidence that the makers either had seen such animals, or knew at least that they existed." Not necessarily-for they may "be rude attempts at imitating animals" of the New World. The mounds of the United States indicate that an intercourse existed between different tribes and peoples remotely separated; and, why could not peoples, while trafficking to, or emigrating from extreme points, carry with them impressions sufficiently forcible for "rude attempts at imitating," and the peccary, the tapir, and the llama, perhaps have been the models for the production of some of these apparently "Old World animals?"

Dr. Rau objects to "potstone" as a material for endurance, whereas it is found in the mounds in better state of preservation than clay pottery. He has not been made aware; perhaps, that the element of fire has caused much ntore damage to these carvings than "exposure." IIe may remember that the "carvings" were coated over with a greasy-looking soot-for their better protection, possibly, as the coating was made to penetrate well into the surface of the stone. Nevertheless, many of them are in a very bad condition. But if there were not well-preserved antiquities-and imitations also-in an admirable state of decrepitude, even in the museums, I conceive that there are more important matters to be considered in connection with these carvings than the material of which they were made.

In conclusion, it is perhaps to be regretted that Dr. Rau has not in his communication suggested any satisfactory explanation of the "curious stone carvings from the neighbourhood of Mount Pisgah, and that he leaves the subject with such dubious language as "modern intrusion." "MANN S. VALENTINE

Paris, July I 7

\section{Movable Coils}

Mr. E. OßACH's letter contains informati on which I am much pleased to o tain. Besides Messrs. Siemens' use of fine aluminium wire for a relay, Mr. Varley stated that it had been tried by his brother or himself for the moving coil of a syphon recorder, but without notable advantage over gold. With such currents as would be available in these two cases, no doubt slight variations in resistance would be of the utmost detriment. With the small but high-tension currents of an induction-coil, the case is materially different; whereas the lightness of the moving coil, as I endeavoured to show, enables currents "of moderate intensity" to be appreciated.

The resistance of $\mathrm{I}$ metre of copper wire I millim. in diameter is given in Sabine's tables as I '06 as comparea with silver, and that of aluminium I'94. I find the the weight of the two to be respectively 2.7 and 0.99 grammes. This is, of course, when both are silk-covered. The ratio between the densities of pure copper and aluminium is $3 \% 44$. The silk covering lessens the aggre zate weight of the copper, and increases that of the aluminiun, so liuat the ratio becomes $2 \cdot 72$.
It is, however, obvious that, weight for weight, aluminiu. will carry much more electricity than copper.

The junctions of gold and aluminium have hitherto given no trouble, nor has the total resistance of the little dynamometer altered; though it has had a double railway journey, partiy in third class, of about I 20 miles.

14, Dean's Yard, Westminster, S.W., July 15

\section{The Analysis of the Tuning Fork}

WiTH reference to the letter of Mr. Stanley in NATURE, vol. xxvi. p. 243, I notice the following sentence:- "If we may apply this principle to stringed instruments, we must look rather to the bridge than the transverse motion of the string, as the communicator of the sonorous vibrations which produces the note." I thought that this was an admitted fact. Upon the shape of the bridge depends the tone of the instrument, as was satisfactorily settled by Stradivari. The bridge is usually made of spotted maple, and its thickness is of the greatest importance, for if it is too thick it will fail to respond to the string vibration. A plain piece of wood as a bridge is absolutely useless, and the tone increases as the proper shape is approximated to.

Rugby, July I4

GeORge Rayleigh Vicars

\section{The Chemistry of the Planté and Faure Cells}

I HAVE read with much interest the important researches of Dr. Gladstone and $\mathrm{Mr}$. Tribe into the chemistry of lead secondary batteries, and my own experience has been in general very confirmatory of their conclusious ; but $I$ am in a difficulty concerning one point in their third article, which appeared in your last issue, and I should be glad to be allowed to ask a question.

The conclusion that during discharge the reduced spongy lead is changed to sulphate of lead is, no doubt, the natural one, and it appears to be confirmed by the analysis of iMessrs. Gladstone and Tribe; but then, if this is the sole product, how is the cell able to be recharged? For I find that if the plates are spread originally with $\mathrm{PbSO}_{4}$, instead of with minium, it is scarcely possible to charge the cell. The coating to be oxidised will indeed allow itself to be acted on very slowly, but the coating to be reduced remains perfectly unchanged. This led me to suppose that the sulphate formed on discharging a cell was perhaps so intimately mixed with some oxide that the reducing action could as easily go on as at the first formation of the cell. But this hypothesis scarcely seems borne out by Messrs. Gladstone and Tribe's results ; for though a"good deal of unaltered peroxide is found after discharge on the one plate, yet on the other they speak of sulphate as being ultimately the sole product of the discharge. It may be that they used a large excess of acid in their cells, but if so, it would be interesting to know whether either of the discharged plates refused to charge up again.

I doubt very much whether, in the cells of commerce, there is anything like enough acid present to combine with all the lead, and $I$ think that in these a great part of the spongy lead would have to be content to oxidise itself somewhat and so remain ready to be reduced again when the charging current $i$ s applied. I by no means deny that sulphate mixed with other things can be acted on, but I do find that it is reduced with some difficulty, and when by itself not at all.

I hope, however, that my question may be the means of eliciting further information from the more extensive experience of Messrs, Gladstone and Tribe

University College, Liverpool, July I $_{4}$

\section{A Curious "Halo"}

I TAKE the liberty of communicating an observation made on Saturday evening last between 8 o'clock p.m. and $8 \cdot \mathrm{I} 5 \mathrm{p} . \mathrm{m}$. of a sort of halo which appeared in the east-south-east, just over Killiney Hill. Near the horizon was a bank of heavy, slategray clouds coming up from the south, and from behind rose up a principal beam from the Telegraph Hill, Killiney, with two side beams of lesser intensity on the sides, at angles of about $28^{\circ}-30^{\circ}$ were lesser beams diverging from the common centre.

All those beams were dark, or appeared so against the sky. I mention the appearance, as the weather since has been singularly cold and rainy for the season.

Royal College of Science for Ireland, Stephen's Green, Dublin, July I7 